Document de treball 2004/5:

\title{
Yardstick competition and the political costs of raising taxes: An empirical analysis of Spanish municipalities
}

\author{
Núria Bosch, Albert Solé
}

\author{
Institut d'Economia de Barcelona \\ Espai de Recerca en Economia \\ Facultat de Ciències Econòmiques i Empresarials \\ Universitat de Barcelona \\ Av. Diagonal, 690 \\ 08034 Barcelona \\ Tel.: 934034646 \\ Fax: 934021813 \\ E-mail: ieb@pcb.ub.es \\ http://www. pcb.ub.es/ieb
}




\title{
YARDSTICK COMPETITION AND THE POLITICAL COSTS OF RAISING TAXES: AN EMPIRICAL ANALYSIS OF SPANISH MUNICIPALITIES ${ }^{a}$
}

\author{
Núria Bosch, Albert Soléb
}

\begin{abstract}
We test the 'yardstick competition' hypothesis by looking at the effects of property tax increases both in the locality and in other comparable jurisdictions on the incumbents' vote. In order to obtain unbiased estimates of the effects of taxes on voting, we account for national political shocks, ideological preferences of the citizenship and government traits, and we estimate the vote equation using instrumental variables. We also allow various traits of the government (ideology, coalition government, and first term government) to mediate the effects of taxes on voting. The vote equation was estimated using a large database containing nearly 3,000 Spanish municipalities and analysing three local elections (1995, 1999 and 2003). The results suggest that property tax increases, both at municipality and neighbourhood level, have a non-negligible impact on incumbent votes, and that this impact is especially high when: the government is right-wing, is a coalition, and is not in its first term.
\end{abstract}

Keywords: Yardstick competition, voting, local government, taxes

JEL Classification: H71; H73

RESUMEN: Contrastamos la hipótesis de "competencia referencial" a través del examen de los efectos sobre los votos obtenidos por el partido en el gobierno de un aumento de los impuestos sobre la propiedad en una determinada localidad y en otras jurisdicciones comparables. A fin de poder obtener estimaciones insesgadas de esos efectos, tenemos en cuenta los shocks acaecidos en la política nacional, las preferencias ideológicas de los ciudadanos y las características del gobierno, y estimamos la ecuación de votación utilizando variables instrumentales. Consideramos, también, varias características del gobierno (ideología, gobierno de coalición y gobierno en su primer mandato) para mediar los efectos de los impuestos sobre el voto. La ecuación de votación fue estimada utilizando una base de datos de cerca de 3.000 municipios españoles y el análisis de tres elecciones locales (1995, 1999 y 2003). Los resultados sugieren que los incrementos en el impuesto sobre la propiedad, tanto a nivel del municipio como de aquellos circundantes, tienen un impacto nada despreciable sobre los votos obtenidos por el partido en el gobierno, y que tal impacto es especialmente elevado cuando el gobierno es de derechas, forma una coalición y no está en su primer mandato.

Palabras clave: Competencia referencial, votación, gobierno local, impuestos Clasificación JEL: H71; H73

\footnotetext{
${ }^{a}$ Comments are welcome. The opinions expressed in the paper do not necessarily reflect the IEB's opinions.

${ }^{\mathrm{b}}$ Corresponding address:

N. Bosch: nbosch@ub.edu / A. Solé: $\underline{\text { asole@ub.edu }}$

Departament d'Hisenda Pública

Facultat de Ciències Econòmiques i Empresarials

Universitat de Barcelona

Av. Diagonal, 690, Torre 4, 2a planta

08034 Barcelona
} 


\section{Introduction}

In many countries, taxes are a fundamental issue of the local political agenda. The high level of visibility of some local taxes ${ }^{1}$ mean that voters may be both aware of the money taken from their pockets by the local council and ready to vote against a tax increase (Stults and Winters, 2002). Tax increases, however, are often necessary to ensure the viability of public services, so it may not always be wise to vote against them. The fundamental problem here is one of asymmetric information, since it is difficult for voters to ascertain if the tax increase is justified or is the result of politicians' profligacy. In this setting, theoretical papers have demonstrated the optimality of voting based on retrospective strategies, e.g. dismissing the incumbent if the tax increase exceeds a critical level (Ferejohn, 1986; Rogoff, 1990). This critical level must be chosen in order to put pressure on the incumbent without leading to too high a probability of dismissing "good" politicians. This means that even in this case, local politicians will be able to obtain some income at the expense of the voter.

However, in a decentralised system, there are other possible (and more efficient) strategies for disciplining the incumbent. Voters might use other jurisdictions as a yardstick against to which evaluate the fiscal performance of their own government. They might consider that tax increases are necessary only if taxes also increase in comparable jurisdictions and, thus, punish incumbents that enact tax increases that are not in line with the increases passed in the neighbourhood. Yardstick competition was originally proposed by Shleifer (1985) as a way of improving the regulation schemes of franchise monopolies, and was first applied to the analysis of competition between sub-national governments by Salmon (1987). This author suggests that one of the main advantages of decentralisation is that it provides local governments with incentives to behave efficiently and to outperform governments in other jurisdictions. Besley and Case (1995) formalise this idea in a political agency model, finding that in the presence of asymmetric information on the cost of providing public services, voters can use information on tax increases in comparable jurisdictions when deciding whether or not to re-elect the incumbent

\footnotetext{
${ }^{1}$ This is a trait often attributed to the property tax, which is the figure analysed in this paper. For example, it is often argued that the tax is highly visible, since "it is assessed on what is typically the household's biggest consumption and investment item" (Wassmer, 1993).
} 
government, and that incumbents are compelled to take into account this 'comparative voting' behaviour and to keep taxes in line with those in the neighbourhood ${ }^{2}$.

The 'yardstick competition' theory provides therefore two different testable hypothesis. Firstly, the 'comparative voting' hypothesis states that a tax increase will have adverse electoral impacts only when it is not simultaneously accompanied by tax increases in neighbouring municipalities. Put another way, votes are reduced by a tax increase but increased by a similar increase in the neighbourhood. Secondly, the 'tax-mimicking' hypothesis states that incumbents will tend to mimic the tax decisions taken by governments of other jurisdictions considered comparable (Besley and Case, 1995). There are some papers in the literature that search for this mimicking behaviour by looking for spatial correlation between tax rates and/or tax changes in neighbouring jurisdictions (Besley and Case, 1995, Heyndels and Vuchelen, 1998, Feld et al. 2001, Revelli, 2001; Bordignon et al., 2003 and 2004, and Solé-Ollé, 2003). However, the problem with this empirical approach is that it is very difficult to distinguish between the spatial tax interactions that arise because of 'yardstick competition' and those that arise because of 'tax competition' for mobile resources (Brett and Pinske, 2000, Brueckner and Saavedra, 2001, Buettner, 2001), since both hypotheses lead to the specification of a tax reaction function with a spatial lag parameter ${ }^{3}$.

Nonetheless, there are only a few papers that attempt to directly test the 'comparative voting' hypothesis, by looking at the effects of neighbours' tax increases on the electoral results. Besley and Case (1995) carry out this test with data from the US states, finding evidence of comparative voting behaviour. The same test is carried out by Revelli (2002) and Vermeier and Heyndels (2004), for UK and Flemish local governments, respectively, although with less conclusive results. In this paper, we follow the latter approach and estimate the effects tax increases both in the voters' municipality of residence and in the neighbouring ones on the electoral results of the incumbent party (or parties). The test is carried out using data on nearly 3,000 Spanish municipalities for which we have

\footnotetext{
${ }^{2}$ Extensions to this basic model include papers by Wrede (2001), Besley and Smart (2001), and Bordignon et al. (2003).

${ }^{3}$ Several authors try to untangle these two hypotheses by allowing the neighbours' tax rates to interact with some political factors. They find, for example, that interactions are higher when electoral margins are low (Bordignon et al., 2003, and Solé-Ollé, 2003) or when governors are not in their last term of office (Besley and Case, 1995).
} 
assembled detailed data on the property tax rate for the period 1990-2003, and data on the electoral results of three local elections (i.e., 1995, 1999 and 2003).

In estimating the vote equation, we will use the recommendation of the extensive literature on estimation of popularity functions and economic voting (see Paldam, 1997, for example). We will control for the influence of underlying political factors such as national political shocks and the ideological bias of the voting population. We will also take into account the possible endogeneity of tax increases, estimating the vote equation using Instrumental Variables, and paying special attention to the reliability of the instruments used. Each of the papers mentioned above accounts for some of these aspects, but omits others. For example, although Besley and Case (1995) estimate the equation using Instrumental Variables, they do not include any control to account for the influence of national political shocks. The only paper that includes all of these steps is that by Revelli (2002) which finds that the results obtained depend to a great extent on these econometric considerations.

It may in practice be very difficult to find instruments that are simultaneously valid and not weak. Although we have been able to find instruments that are reasonably strong, we will therefore also follow the suggestion of Stults and Winters (2002) which recommends allowing different traits of the government (in this case ideology, coalition government, and first-term government) to mediate the effects of tax increases on voting, both in the municipality and in the neighbourhood. These interaction effects may help to identify the effect of tax increases on vote results, given the problem of endogeneity mentioned above.These interaction effects are of course interesting in themselves, because they allow us to identify specific instances where a tax increase will cause significant electoral losses and, equally importantly, where the fiscal externality caused by a tax change in the neighbouring jurisdictions will have a stronger effect on the vote for the incumbent.

The paper is organised as follows. In the next section we describe how we test our hypothesis, beginning with a brief description of local taxation and politics in Spain, followed by a presentation of the vote equation, the econometric method and the database used. The results of the estimation of the vote equation are presented in section three. Finally, the fourth section offers a conclusion. 


\section{Empirical design}

In this section, we describe the empirical design we use in order to test the effect of property tax increases in both the municipality and the neighbourhood on the votes received by local governments in the election following the tax increase. The test will be performed with a large and unique database of nearly 3,000 Spanish municipalities with over 1,000 inhabitants during three electoral periods, delimited by the elections of 1991, 1995, 1999 and 2003. This section is organised as follows. Firstly, in order to set the scene for the analysis and to provide some information that we consider important to understand some methodological decisions taken afterwards, we give a brief description of the Spanish local taxation and political system. Secondly, we present the specification used to test the hypothesis advanced above. Third, we describe the data base and the econometric techniques used.

\subsection{Local taxes and politics in Spain}

Local taxation. Spain consists of more than eight thousand municipalities, but most of these are quite small (i.e., 90\% have less than five thousand inhabitants and represent no more than $5 \%$ of the Spanish population). These municipalities are multi-purpose governments, and their major expenditure categories are the traditional responsibilities assigned elsewhere to the local public sector (i.e., environmental services, urban planning, transportation, welfare, etc.) with the exception of education, a responsibility of regional governments in Spain. Municipal responsibilities grow steadily with population size, something that is duly recognised by the financing system.

Own revenues account for more than $65 \%$ of municipal current revenues, with the remaining $35 \%$ being covered by grants, most of which are unconditional. Two thirds of the municipality's own revenues come from five taxes and the remaining one-third from a variety of user charges. The main taxes are the property tax, the local business tax and the local motor vehicle tax, which respectively account for $50 \%, 20 \%$ and $15 \%$ of tax revenues ${ }^{4}$. The property tax is the only one that will be considered in the empirical analysis. There are two reasons for this decision. The first of these is that as it is the main local tax, it is also the focus of most of the taxpayer's political discontent. Not only the yearly decision on the nominal tax rate, but also the less frequent decision to reassess the

\footnotetext{
${ }^{4}$ The other two taxes are a tax on land value improvements and a tax on building activities.
} 
property values of a municipality may entail significant political risks. The second reason is that we have been not able to include information on the business and vehicle tax rates in the huge database assembled for this paper. The main risk of this option is that the effect of the property tax rate may finally picks up the discontent of citizens with other taxes not included in our vote equation. We believe this risk is not very high given that the correlation among the tax increases of the three taxes does not seem to be very high ${ }^{5}$.

In the early years of democracy, Spanish municipalities did not have any power to set property tax rates. However, at the end of the 1980s they were granted with the power to set the rates of the local taxes above a certain threshold, and above a completely harmonised tax base. There is a minimum nominal property tax rate of $0.4 \%$ of the assessed property value which is the same for all municipalities. This minimum tax rate is allowed to fall to $0.1 \%$ during the five years following a reassessment. The maximum nominal tax rate increases with population size, ranging from $0.85 \%$ for municipalities with less than 5,000 inhabitants to $1.1 \%$ for municipalities with more than 100,000 inhabitants. Additional points may be applied if a municipality complies with some other conditions, including being a regional capital $(+0.07 \%)$, having an urban transportation system $(+0.07 \%)$, and providing more services than the ones defined as compulsory by law $(+0.06 \%)$. As a result of the use of this tax autonomy, the disparities in property tax rates among municipalities are now considerable. Furthermore, the use of tax room is expected to continue in the future, since only a few municipalities have reached the top tax rate.

The good health of the local property tax depends a great deal on the frequency and quality of property value reassessments. In Spain, an agency of the central government ('Centro de Gestión Catastral y Cooperación Tributaria') is responsible for doing this job. The reassessment system is thus the same throughout the country. However, a lack of resources and also political opposition often delay reassessment campaigns and, in practice, only a small fraction of municipalities are reassessed each year. Although the responsibility for the reassessment is a central one, in practice it is quite difficult to begin the process without the consent of the municipal government. In this sense, reassessments

\footnotetext{
${ }^{5}$ In fact, we computed this correlation with the data available from only one Spanish region (the province of Barcelona, with data from the Diputación de Barcelona for various years) and the correlation between the increase in the property tax rate and the increase in business and vehicle tax rates was only 0.08 and 0.12 , respectively.
} 
are not truly exogenous. The average delay between two consecutive assessments can be substantial (e.g., 8 years in 1999; see Table 1). Because of this delay, a reassessment leads to a considerable jump in assessed values and although nominal tax rates are adjusted downwards, effective tax rates tend to increase by a considerable amount. This is the reason why political opposition to a property reassessment is usually quite high. Only strong governments or governments with financial problems are willing to take such a risk.

Local politics. The local political system in Spain is similar to other systems operating in Europe (Colomer, 1995). Municipal elections are held simultaneously in all the municipalities at regular periods (every four years). Voters elect a given number of councillors that grows with the population of the municipality. These councillors in turn elect the mayor and he/she allocates the various local government posts among the councillors belonging to the party (or parties) that support him/her. During the period analysed, between 60 and $70 \%$ of the municipalities in the sample analysed were governed by majorities (see Table 1), while the remaining governments may be classified either as coalitions or as minority governments. Both coalitions and minority governments need to win the approval of more than one party in order to pass the budget (at the end of the previous year) and the fiscal ordinances setting the tax rates of the various local taxes and the sums of the local user charges (usually approved before the budget). Although failure to approve these documents does not lead to fresh elections (since these can be held only every four years), the budget process is determined by the possible break-up of the coalition government or by the formation of an alternative winning coalition by the parties in the opposition, in the case of a minority government. Although the power of the mayor regarding tax issues is therefore considerable, the fact that many governments are coalitions or minorities is a clear constraint on what he/she can do in that field, since the mayor can be dismissed by an alternative coalition at any time. There has been some concern in Spain regarding the instability of local coalition and minority governments, and the difficulty that they find in taking decisions regarding their budgets and other issues.

In addition to the above, most of the candidates are aligned along national or regional party lines. In fact, the municipal political system is seen as a first step in the recruitment process of the regional and national political elite (Magre, 1998). In Spain, there are two 
main national left-wing parties (PSOE (socialists), which formed the central government during the period 1983-96 and from 2004 to date and IU (former communists)) and one national right-wing party (PP, which formed the central government from 1996 to 2004). There are also many parties of a regional nature, some of which are on the left and some on the right but with nationalism or regionalism as a salient issue ${ }^{6}$. There are also many local parties or candidates running as independents, mostly in small municipalities. It is very difficult to ascertain the ideological position of these parties.

\subsection{The vote equation}

We wish to estimate the effects of taxes (both in the municipality and in the neighbourhood) on the votes obtained by the local government. It is not absolutely clear how to proceed in the specification of this equation in multi-party systems with many coalition governments. Most of the previous literature on the political costs of taxation comes from the U.S. ${ }^{7}$. Because the U.S. is a two-party system, the authors are able to use the vote share of one of the parties as a dependent variable, giving different responses to each of the explanatory variables if the party is the incumbent or the challenger (see, e.g., Peltzman, 1992, Lowry et al., 1998). This procedure will be difficult to apply in our case, given the high number of parties and the fact that in practice a party may play more than two roles ${ }^{8}$.

In our case it therefore seems better to use the vote share of the parties in the governing council as the dependent variable. The few papers to analyse the effects of taxation on multiparty systems have followed this procedure (see for example Royed et al., 2000, Landon and Ryan, 1992, and Vermeier and Heyndels, 2004). However, we also use the vote share of the main party in the government in addition to this variable, which is the

\footnotetext{
${ }^{6}$ The most relevant in terms of local governments controlled are CiU and ERC (right and left-wing, respectively, both in Catalonia), UV (right-wing, in Valencia), and BNG (left-wing, in Galicia), but there are one or two in each region.

${ }^{7}$ Early U.S. analyses include Pomper (1968 and 1976), Turett (1971) and Hansen (1983) and there are plenty more recent papers (Kone and Winters, 1983; Niemi et al., 1995; Brooks and Prysby, 1992; Besley and Case, 1995, and Lowry et al., 1998). There are a few papers on this outside the U.S.: in Canada (Landon and Ryan, 1997), in Belgium (Vermeier and Heyndels, 2004), and in the UK (Gibson, 1988; Gibson and Stuart, 1992; Rallings and Thrasher, 1997; Revelli, 2002). The studies of Belgium and the UK are especially interesting, because they are the only ones to refer to the local property tax which is the focus of the paper.

${ }^{8}$ For example, apart from being incumbent or a challenger, a party may be a coalition partner or may not even stand in many municipalities.
} 
mayor's party in the vast majority of cases. Of course, these two equations are equivalent in the case of a majority government. However, they differ in the case of a coalition. In this case by estimating both the vote for the government and the vote for the party of the mayor, we are able to evaluate which member of the coalition -the main party or its partners - suffers most from tax increases ${ }^{9}$.

Basic specification. With $v_{i, t}$ being the vote share of either the parties in the local government or the main party in municipality $i$ just before election $t$, the equation we use in the analysis is:

$$
\begin{aligned}
v_{i, t}= & \alpha_{1} \cdot \Delta t_{i, t}+\alpha_{2} \cdot \Delta \mathrm{Wt}_{i, t} \\
& +\alpha_{3} \cdot \Delta y_{i, t}+\alpha_{4} \cdot \Delta \mathrm{W}_{i, t}+\alpha_{5} \cdot v_{i, t-1}+\alpha_{6} \cdot z_{i, t}+\alpha_{7} \cdot \bar{v}_{i, t}+f_{r, t}^{p}+\varepsilon_{i, t}
\end{aligned}
$$

where $\Delta t_{i, t}$ and $\Delta \mathrm{W} t_{i, t}$ are tax rate increases set by the municipality and by its neighbours during the four-year period before the election date $t^{10}$. In this paper, we will limit our analysis to the effect of increases on the rate of the property tax, the main local tax in Spain. The term W is a weights matrix that identifies the pairs of municipalities that are considered neighbours. More details about the weighting scheme used are provided below. The terms $\Delta y_{i, t}$ and $\Delta \mathrm{W} y_{i, t}$ are vectors of variables measuring the evolution of the local economy in the municipality and in the neighbourhood (e.g., growth in unemployment and population) during this four-year period. It is unclear that the voters hold local politicians accountable for the development of the economy, since given the small size of Spanish municipalities, their opportunities to improve the situation are limited. Nonetheless, it is also true that economic promotion (i.e., making efforts to bring economic activity to the locality) is a prominent issue on the local political agenda in Spain. We introduce measures of the neighbourhood's economic situation in order to analyse the possibility of 'comparative economic voting'.

\footnotetext{
9 See Anderson (1995 and 2000) and Wilkin et al. (1997) for analysis allowing for disaggregated government support for the party of the prime minister and its coalition partners.

${ }^{10}$ We have also estimated the equation allowing for different effects of tax increases enacted at diffe-rent points of the four-year period. We will comment on these results at the end of the next section.
} 
The lagged vote share, $v_{i, t-1}$, is introduced to account for persistent shocks that may have an effect on the popularity of the government. Persistence in the vote share would suggest that once in power it becomes more difficult to lose the support gained from the public, thus giving an indication of some kind of 'incumbency advantage' (see for example, e.g., Lowry et al., 1998). We also include a vector of political characteristics in the equation, $z_{i, t}$, which controls for the effects on the vote of having a coalition government or a government that is in its first term. The effect of these variables is unclear, but we may hypothesise, for example, that voters tend to punish coalitions for their incapacity to deal with problems quickly and efficiently. We may also expect that voters tend not to punish governments in their first term of office so severely, giving them confidence to develop the electoral program. This 'honeymoon effect' would disappear in subsequent terms of office (see, e.g., Veiga and Veiga, 2004) ${ }^{11}$.

We include two additional controls in the equation to account for other unmeasured political factors. Firstly, we also include as a control variable the average vote share of the parties in the first three municipal elections held after the establishment of democracy (i.e., those of 1979,1983 and 1987) ${ }^{12}$. This average vote share, $\bar{v}_{i}$, aims to capture the long-run idiosyncratic attachment of a municipality to a given party.

Secondly, we include a set of regional election-party effects, $f_{r, t}^{p}$, which measure the popularity shocks experienced by the parties analysed at regional level. We deal with regional-election-party effects econometrically by including a dummy for each triplet of election, region and party. As explained in more detail in the next section, we will use both a complete list of parties and a smaller set of categories grouping the various parties according to ideology. The reason that led us to account for these popularity differences (across elections and municipalities and for the different parties) is that ideology is quite

\footnotetext{
${ }^{11}$ It must be acknowledged that Veiga and Veiga (2004) have a much shorter period than four-years in mind when talking about this 'honeymoon effect'. These authors are able to analyse the effects on the popularity of the government using survey data, so they have yearly data. We are only able to measure the popularity of the local government when an election is held, so the only thing we can do is try to differentiate between newly-elected and longer-established local governments.

${ }^{12}$ We will analyse the effects of tax increases on the results of the local elections of 1995, 1999 and 2003, using the lagged vote among the explanatory variables (i.e., that of the elections of 1999, 1995 and 1991, respectively) and the average vote share of the 1979, 1983 and 1987 elections. Note that the electoral results used to compute these two explanatory variables do not overlap.
} 
important in Spanish local elections, and the main ways to identify ideological messages are the national party's commitments. This means that many voters tend to vote for the same parties irrespective of the election (i.e., national or local) and that there is a kind of contagion across elections. Although we believe that local politics count, it is therefore also true that there is a positive connection between the popularity shocks suffered by a party at a national or regional level and its results at a local level. These shocks may be correlated with the general trends in taxation in localities governed by a given party and, the results of our analysis may therefore be biased if we do not control for these influences. In fact, results by Revelli (2002) for the UK reveal that the conclusions about the electoral costs of taxation may be altered when accounting for the influence of national politics ${ }^{13}$.

Interactions. We then estimate whether the effects of tax increases (in the municipality and in the neighbourhood) on the electoral results depend on the political traits of the local government. In order to account for the effects of the political context on the electoral costs of raising taxes we estimate the following interaction equation:

$$
\begin{aligned}
v_{i, t}= & \left(\alpha_{10}+\alpha_{11} \cdot \mathrm{RIGHT}_{i, t}+\alpha_{12} \cdot \mathrm{COA}_{i, t}+\alpha_{13} \cdot \mathrm{NEW}_{i, t}\right) \cdot \Delta \mathrm{t}_{i, t} \\
+ & \left(\alpha_{20}+\alpha_{21} \cdot \mathrm{RIGHT}_{i, t}+\alpha_{22} \cdot \mathrm{COA}_{i, t}+\alpha_{23} \cdot \mathrm{NEW}_{i, t}\right) \cdot \Delta \mathrm{Wt}_{i, t} \\
+ & \alpha_{3} \cdot \Delta y_{i, t}+\alpha_{4} \cdot \Delta \mathrm{W}_{i, t}+\alpha_{5} \cdot v_{i, t-1}+\alpha_{6} \cdot z_{i, t}+\alpha_{7} \cdot \bar{v}_{i}+f_{r, t}^{p}+\varepsilon_{i, t}
\end{aligned}
$$

where $\mathrm{RIGHT}_{i, t}=1$ if the parties in the local government have a right-wing ideology and 0 in the case of left-wing parties, $\mathrm{COA}_{i, t}=1$ if there is more than one party in the local government and 0 if there is only one party, and $\mathrm{NEW}_{i, t}=1$ if the government is in its first term of office and 0 if not. Note that the parameter $\alpha_{10}$ measures the effect of increased property tax rates for the base category, i.e. for tax increased by a majority leftwing government that is not in its first term of office.

\footnotetext{
${ }^{13}$ Revelli (2002) controls for these time-invariant political preferences by including a set of municipal-party fixed effects. This procedure is not appropriate in our case since, given the reduced number of elections, it is evident that we can not include such a large number of dummies in the equation. Note also that these effects could not be eliminated by first-differentiation. This is due to the fact that the variable we are analysing is the vote share of the government parties, which need not be the same in two consecutive elections. The municipal-party effect in $t$ and $t-1$ may therefore refer to different parties or coalitions of parties. Note that elimination of party-specific effects would be possible if our dependent variable was the vote share of one party (the same in all the elections analysed).
} 
There are various reasons justifying interest in these interaction results. Firstly, these interaction effects may help also in the identification of the effect of tax increases on election results, given the possible endogeneity of the tax variables (more on this below). In fact, given the difficulty in finding suitable instruments for the tax increase, some authors propose correcting the problem by merely interacting the tax increase with political context dummies (see Stults and Whitten, 2003, for example). Since (as will become clear below) we have been able to find valid instruments for our tax variable, we do not rely exclusively on this procedure to identify the effects of taxes on the vote. Nevertheless, we consider that our results based on tax increase interactions improve confidence in the quality of the estimates. Secondly, these interaction effects may be interesting in themselves, because they allow us to identify specific instances where a tax increase will cause significant electoral $\operatorname{losses}^{14}$ and, equally importantly, where the fiscal externality caused by a tax change in neighbouring jurisdictions will have a stronger effect on the vote for the incumbent.

The economic voting literature helps us to formulate some predictions regarding the sign of the coefficients in (2). In the case of ideology, some authors (Alesina and Rosenthal, 1995) have argued that voters do not judge all parties equally, but instead have different expectations regarding what is a reasonable policy depending on the ideology of the party. This means that voters hold parties more responsible for their most salient goals, punishing the right more severely for tax increases. Lowry et al. (1998) show that this is indeed the behaviour of voters in US gubernatorial elections, where Republicans are penalised more severely for tax increases than Democrats ${ }^{15}$. Ideological differences between left and right-wing parties are more marked in Europe and Spain than in the US, even at a local level.We therefore expect that left-wing local governments will be punished less for the municipality's tax increases than right-wing governments.

However, this previous literature does not address the question of how ideology affects the yardstick effects. In fact, in the traditional analysis (Lowry et al., 1998) taxes are a

\footnotetext{
${ }^{14}$ Recent research on the link between tax increases and elections indicates a variable impact depending on the type of tax raised and the political context surrounding a specific episode (Kone and Winters, 1983; Niemi et al., 1995; Brooks and Prysby, 1992; Besley and Case, 1995, and Lowry et al., 1998).

${ }^{15}$ Many papers in the empirical literature on economic voting have found that left-wing governments are more heavily penalised for unemployment increases while right-wing governments are more heavily penalised for inflation increases (see Powell and Whitten, 1993; Veiga and Veiga, 2004).
} 
measure of government intervention, while in the yardstick model taxes (and the comparison of taxes with those in the neighbourhood) are a measure of politicians performance. Since it is not evident that left- or right- wing voters care differently about governments wasting money, neither is it evident whether yardstick effects should differ. From our point of view, the problem here is that both theoretical models deal with a relevant but partial portion of the reality, and that there is no attempt in the literature to develop a model capable of accounting for all these facts. Since this is not the purpose of our paper, we will simply give some intuition in order to suggest the possibility of differential yardstick effects regarding ideology. We begin by noting that the yardstick model (Besley and Case, 1995; Revelli, 2002) assumes that the level of local public goods is constant and that local spending only changes because of a cost shock or because of politicians' profligacy. However, with ideological preferences, the level of spending may increase when a left party takes office because of a higher level of local public goods desired. If this is the case, it may be difficult for voters to judge the efficiency of the government by making tax comparisons and, therefore, both the municipality's tax increases and tax increases in the neighbourhood may have a lower impact on the vote in the case of a left-wing government ${ }^{16}$. In the absence of a more detailed theoretical treatment of this hypothesis, it is difficult to say more about it. The empirical results will tell us if there is any basis for this intuition.

The second hypothesis implicit in equation (2) is that voters react differently to tax increases enacted by coalitions. The so-called "clarity of responsibility" hypothesis states that the impact of economic variables on voting will be greater for governments with a greater clarity of responsibility (Powell and Whitten, 1993). Put another way, with a government with many different members, voters have many difficulties in ascertaining which of the parties is really responsible for the tax increase. Given this uncertainty, voters may decide not to punish any of these parties for the decisions taken. There is some empirical evidence for the validity of this hypothesis. For example, Powell and Whitten (1993) and Anderson (1995) have found evidence that coalition governments are punished less than majorities for unemployment and inflation. In the case of the US,

\footnotetext{
${ }^{16}$ For example, imagine the discussion between the left-wing government and the right-wing opposition in the city council regarding the yearly tax increase. The opposition argues that the increase is excessive in the light of other tax increases in the neighbourhood, but the government answers that the comparison is not legitimate given that these increases are needed in order to finance a set of service improvements included in the electoral program.
} 
Lowry et al. (1998) find that divided state governments face lower electoral costs of taxation than unified governments (i.e., when the same party controls both the executive and the legislative $)^{17}$. We consider that in this case, there is no major problem in extending this hypothesis to the effect of neighbour's tax increases. Voters may use relative tax increases in order to measure governments' waste, but find it difficult to identify which party is responsible for this waste.

The third hypothesis implicit in (2) is that voters seem to be less demanding of newly elected governments (i.e., governments that are in their first term) than of longerestablished governments. This could be termed a 'honeymoon effect' and may be explained by the fact that voters are willing to wait and see until the new government has implemented its program, i.e. there is some confidence that the tax increases enacted by a new government are justified by the need to apply a new policy. However, once this period elapses, this confidence erodes and voters are less willing to tolerate further tax increases. Although we have found no papers analysing the relationship between this 'honeymoon effect' and the electoral costs of tax increases, there are some papers in the literature on economic voting that have documented its relevance (see Veiga and Veiga, 2004, for example). We will account for this possibility and analyse whether vote losses caused by property tax increases are indeed lower during the first term of a local government. This hypothesis can also be extended to the impact of neighbours' tax increases. The argument here is similar to that used in the case of ideology. Voters expect tax increases in the first term in order to finance the electoral program of the new government, and feel that it is not yet legitimate to make tax comparisons. Again, the empirical results will tell us if this intuition is justified by the facts or not.

\subsection{Data}

We estimate the vote equations using information from 2,799 Spanish municipalities for the period 1991-2003. We combine information on the electoral results of the municipal elections of 1991, 1995, 1999 and 2003 with property tax data and some socioeconomic variables for all the years of the period. In order to construct the average vote share for the parties in government, we also use information on the electoral results of the 1979, 1983 and 1987 municipal elections. The property tax database includes all the Spanish

\footnotetext{
${ }^{17}$ Despite this, some authors have questioned the validity of this hypothesis (Royed et al., 2000; Anderson, 2000; Niemi et al., 2002).
} 
municipalities, but for some of the elections, electoral information has only been provided for municipalities with more than 250 inhabitants, and some socio-economic data was available only for municipalities with more than 1,000 inhabitants. We also discarded some municipalities with a mayor belonging to a local party; because of the difficulty of assigning an ideological label to these parties. In the end, we were restricted to the 3,117 municipalities with a population of over 1,000 inhabitants minus the ones with a mayor from a local party and minus some others with data problems, leaving us with the 2,799 municipalities we used in the end. 
Table 1: Definition of the variables, data sources, and descriptive statistics

\begin{tabular}{|c|c|c|c|c|c|}
\hline Variable & Definition & Data sources & Desc & riptive sta & istics \\
\hline & & & Mean & (Standard & Dev.) \\
\hline & & & $1991-95$ & 1995-99 & 1999-03 \\
\hline$\Delta t_{i, t-4}^{e}$ & $\begin{array}{c}\Delta \text { Effective } \\
\text { Property tax rate }\end{array}$ & & 0.155 & 0.157 & 0.152 \\
\hline & $\begin{array}{l}(\Delta \text { in } \% \text { of assessed } \\
\text { property value) }\end{array}$ & $\begin{array}{l}\text { Property tax statistics, Centro } \\
\text { de Gestión Catastral (Ministry }\end{array}$ & $(0.303)$ & $(0.309)$ & $(0.335)$ \\
\hline$\Delta h_{i, t-4}$ & $\begin{array}{l}\% \Delta \text { Urban units } \\
\text { per capita }\end{array}$ & & $\begin{array}{c}7.624 \\
(16.309)\end{array}$ & $\begin{array}{c}6.362 \\
(11.601)\end{array}$ & $\begin{array}{c}3.289 \\
(9.661)\end{array}$ \\
\hline$\Delta u_{i, t-4}$ & $\begin{array}{c}\% \Delta \text { Unemployment } \\
\text { per capita }\end{array}$ & $\begin{array}{l}\text { National Institute of Statistics } \\
\text { (INE) \& Anuario Social de } \\
\text { España (La Caixa) }\end{array}$ & $\begin{array}{l}-5.81 \\
(9.52)\end{array}$ & $\begin{array}{l}-11.63 \\
(21.51)\end{array}$ & $\begin{array}{l}-14.71 \\
(25.60)\end{array}$ \\
\hline$\Delta n_{i, t-4}$ & $\% \Delta$ Population & $\begin{array}{l}\text { National Institute of Statistics } \\
\text { (INE) }\end{array}$ & $\begin{array}{c}2.70 \\
(6.01)\end{array}$ & $\begin{array}{c}1.42 \\
(4.63)\end{array}$ & $\begin{array}{c}3.49 \\
(10.21)\end{array}$ \\
\hline & & & Mean & (Standard & Dev.) \\
\hline & & & 1991 & 1995 & 1999 \\
\hline$t_{i, t-4}^{e}$ & $\begin{array}{l}\text { Lagged Effective } \\
\text { Property tax rate }\end{array}$ & & $\begin{array}{c}0.523 \\
(0.170)\end{array}$ & $\begin{array}{c}0.678 \\
(0.265)\end{array}$ & $\begin{array}{c}0.835 \\
(0.275)\end{array}$ \\
\hline & property value) & & & & \\
\hline$t_{i, t-4}^{\max }-t_{i, t-4}^{n}$ & $\begin{array}{l}\text { Lagged Difference } \\
\text { between Nominal }\end{array}$ & $\begin{array}{l}\text { Property tax statistics, } \\
\text { Centro de Gestión Catastral }\end{array}$ & 0.391 & 0.378 & 0.365 \\
\hline & $\begin{array}{l}\text { and Maximum Property } \\
\text { tax rate }\end{array}$ & & & & \\
\hline$a_{i, t-4}$ & $\begin{array}{l}\text { Number of years from } \\
\text { the last property value } \\
\text { reassessment }\end{array}$ & & $\begin{array}{l}3.901 \\
(3.059)\end{array}$ & $\begin{array}{c}6.604 \\
(7.836)\end{array}$ & $\begin{array}{l}8.066 \\
(3.928)\end{array}$ \\
\hline & & & Mean & (Standard & Dev.) \\
\hline & & & 1995 & 1999 & 2003 \\
\hline & & & Election & Election & Election \\
\hline$v_{i, t}$ & All parties & & $(11.41)$ & $(12.96)$ & $(12.16)$ \\
\hline & $\begin{array}{l}\text { Vote share, } \\
\text { Mayor's party }\end{array}$ & & $\begin{array}{l}49.73 \\
(13.22)\end{array}$ & $\begin{array}{c}49.11 \\
(13.11)\end{array}$ & $\begin{array}{c}49.19 \\
(14.46)\end{array}$ \\
\hline$v_{i, t-4}$ & $\begin{array}{l}\text { Lagged Vote share, } \\
\text { All parties }\end{array}$ & $\begin{array}{l}\text { Municipal Elections database, } \\
\text { Ministry of Interior \& Ministry }\end{array}$ & $\begin{array}{c}59.82 \\
(13.51)\end{array}$ & $\begin{array}{c}60.92 \\
(15.52)\end{array}$ & $\begin{array}{c}60.24 \\
(15.00)\end{array}$ \\
\hline & $\begin{array}{l}\text { Lagged Vote share, } \\
\text { Mayor's party }\end{array}$ & of Public Administration & $\begin{array}{c}52.00 \\
(14.21)\end{array}$ & $\begin{array}{c}50.42 \\
(12.96)\end{array}$ & $\begin{array}{c}49.88 \\
(0.146)\end{array}$ \\
\hline $\bar{v}_{i}$ & $\begin{array}{l}\text { Average Vote share, } \\
\text { All parties }\end{array}$ & & $\begin{array}{c}52.12 \\
(11.65)\end{array}$ & $\begin{array}{c}52.12 \\
(11.65)\end{array}$ & $\begin{array}{c}52.12 \\
(11.65)\end{array}$ \\
\hline & $\begin{array}{l}\text { Average Vote share, } \\
\text { Mayor's party }\end{array}$ & & $\begin{array}{c}46.02 \\
(12.01)\end{array}$ & $\begin{array}{c}46.02 \\
(12.01)\end{array}$ & $\begin{array}{c}46.02 \\
(12.01)\end{array}$ \\
\hline & & & & Mean & \\
\hline & & & 1991-95 & 1995-99 & 1999-03 \\
\hline $\mathrm{COA}_{i, t}$ & $\begin{array}{l}1 \text { if coalition } \\
\text { government, } 0 \text { if not }\end{array}$ & Municipal Elections database, & 0.331 & 0.385 & 0.317 \\
\hline $\mathrm{RIGHT}_{i, t}$ & $\begin{array}{l}1 \text { if government on the } \\
\text { right } 0 \text { on the left }\end{array}$ & $\begin{array}{l}\text { Ministry of Interior \& Ministry } \\
\text { of Public Administration }\end{array}$ & 0.348 & 0.427 & 0.481 \\
\hline $\mathrm{NEW}_{i, t}$ & $\begin{array}{l}1 \text { if government in its } \\
\text { first term, } 0 \text { otherwise }\end{array}$ & & 0.398 & 0.289 & 0.269 \\
\hline
\end{tabular}


The electoral database was compiled from two different files provided by the Spanish Ministry of the Interior and the Ministry of Public Administrations. The first provides information on the votes received by the various parties in the local elections. The second informs us of the number of councillors from each party and of which is the party of the mayor. In order to compute the vote share of the local government $\left(v_{i, t}\right)$ we simply add the votes of the different parties belonging to the local government during the previous four-year mandate and then divide by the number of valid votes. The lagged vote share $\left(v_{i, t-1}\right)$ is computed in a similar manner. Note that in any case, the parties used to compute both the vote share and the lagged vote share are the same -those belonging to the parties in the government during a given four-year mandate. The average vote share of a party or group of parties in charge during a given four-year mandate $\left(\bar{v}_{i}\right)$ is computed with data on the vote share of these parties in the first three local elections held after the beginning of the democratic period (i.e., those of 1979, 1983 and 1987).

The local government is considered a majority (MAJ) if the mayor's party has more than the $50 \%$ of the councillors and otherwise as a coalition (COA). As far as ideology is concerned, there are several studies and surveys quantifying the ideological position attributed by Spaniards to the different parties (Sotillos, 1997; Molas and Bartomeus, 1998). We used these ideological indexes to classify the parties into four groups: left, centre-left, centre-right and right. The regional-party-time dummies were devised using these four categories. For coalition governments, we computed an ideological index for the government as the summation of the ideological index of all the parties in the government weighted by the share of councillors of each of them. With this index, we were able to classify coalition governments in the four categories mentioned above. The interactions with tax increases only include two variables, LEFT and RIGHT, the first one containing governments in the first two categories and the second one the other two. Finally, a local government is classified as being in its first term of office (NEW) if the party of the mayor has changed between one four-year period and the following one. Table 1 provides information on the proportions of local governments in each category.

The property tax database comes from the Ministry of Finance and has been provided by the central government agency responsible for carrying out property value assessments in 
all the Spanish municipalities (the "Centro de Gestión Catastral y Cooperación Tributaria"). This database includes information on each Spanish municipality for the nominal property tax rate, assessed property value, number of homes, and year of the last property value reassessment. We used this information to compute the increase in the effective property tax rate, $\Delta t_{i, t-4}^{e}$, in each of the three four-year periods analysed ${ }^{18}$ :

$$
\Delta t_{i, t-4}^{e}=\Delta t_{i, t-4}^{n}+d r e v_{i, t-4} \times t_{i, r}^{n} \times\left(\Delta v_{i, r} / v_{i, r-1}\right)
$$

where $\Delta t_{i, t-4}^{n}$ is the increase in the nominal property tax rate during the four-year period preceding the election, $\operatorname{drev}_{i, t-4}$ is a dummy equal to one if there was a property value reassessment during this four-year period, $t_{i, r}^{n}$ is the nominal property tax rate the year before the implementation of the new assessed values, and $\Delta v_{i, r} / v_{i, r-1}$ is the increase in assessed values due to the reassessment process compared to the assessed property values just before this new reassessment ${ }^{19}$. If there is no reassessment during a given four-year mandate, the increase in the effective property tax rate therefore equals the increase in the nominal tax rate (i.e., $\Delta t_{i, t-4}^{e}=\Delta t_{i, t-4}^{n}$ ), but if there is a reassessment, it is necessary to compute the increase in the effective property tax rate in the way suggested by expression (3).

We include two variables as economic controls $\left(\Delta y_{i, t}\right)$ in the vote equations: the rate of increase in per capita unemployment in the municipality $\left(\Delta u_{i, t}\right)$ and the rate of increase in the population $\left(\Delta n_{i, t}\right)$. The first variable is frequently used in the literature of economic voting. We think this second variable may also measure the economic success of the municipality. Although we accept that population increases also impose costs on residents, Spanish mayors seem to feel that they tend to bring more benefits, to the

\footnotetext{
${ }^{18}$ It is not clear which is the most appropriate timing of taxation to consider. In fact, one can argue that voters are myopic and do not consider all the tax increases occurring during the four-year term, but only those occurring soon before elections. In the next section we also comment on the further results obtained when considering the tax increases occurring in the first and second half of the four-year term of office separately.

${ }^{19}$ Note that the term $t_{i, r}^{n} \times\left(\Delta v_{i, r} / v_{i, r-1}\right)$ could be interpreted as the change in the nominal property tax rate that is required in order to neutralise the increase in assessed property values and to prevent the average tax liability from increasing.
} 
citizens or to themselves ${ }^{20}$. Given that it seems appropriate to account for economic voting in relative terms, we also include the unemployment and population increases in the neighbourhood $\left(\Delta \mathrm{W} u_{i, t}\right.$ and $\left.\Delta \mathrm{W} n_{i, t}\right)$ in the vote equation.

Tax rate increases in the neighbourhood are computed with the help of the weights' matrix $\mathrm{W}$. This is a $\mathrm{N} \times \mathrm{N}$ matrix, where $\mathrm{N}=$ the number of municipalities, with zeros in the diagonal and with elements $w_{i j}$ different from zero if the two municipalities $i$ and $j$ can be considered neighbours. Note that it is not possible to identify these neighbourhood effects by estimating tax interactions for each pair of municipalities ${ }^{21}$. Therefore, an 'a priori' set of interactions has to be defined and tested instead, as is well established in the "spatial econometrics" literature (see Anselin, 1988). A common procedure for specifying these interactions uses geographic proximity criteria. There is a theoretical justification for using geographical weights if voters are more able to get information on tax rates in the neighbourhood than in farther places. There are several reasons that lead us believe that this assumption is appropriate in our case. Firstly, local tax decisions are normally covered by the local press, reaching specific sub-regions. Secondly, voters are able to get information from the jurisdictions where they work, shop or where their relatives and friends live, and these jurisdictions are usually in the nearby neighbourhood, at least in Spain. Thirdly voters may get comparative information from local opposition parties; these local politicians usually interact more with local politicians in the same region, than with more distant ones ${ }^{22}$. As a result, in this paper we will use a definition of neighbourhood based on pure proximity, with neighbours being defined as municipalities located within a distance of $20 \mathrm{~km}^{23}$. The weights used are therefore $1 / n_{i}$ if there is a

\footnotetext{
${ }^{20}$ As explained above, Spanish municipalities receive more responsibilities, more tax autonomy and higher transfers as their population increases. The enhanced role of larger municipalities is also usually recognised informally by the political market, by enhancing the career prospects of local politicians.

21 This will force us to estimate $2,799 \times 2,799$ parameters, something not possible with $2,799 \times 3$ observations.

${ }^{22}$ For example, a higher tier of local government covering specific sub-regions, issues yearly surveys of budgetary and fiscal data, comparing the situation of each municipality with other municipalities in the same area (see, Diputación de Barcelona, various years, for an example). It is more difficult to obtain comparative fiscal information for all the Spanish territory; in fact, this is one of the first papers to use a database of local tax rates covering all Spain.

${ }^{23}$ This same criterion was used in the tax mimicking analysis in Solé-Ollé (2003). We also tried other criteria, changing the distance to $10 \mathrm{~km}, 30 \mathrm{~km}$ and $40 \mathrm{~km}$, and using inverse distance weights with various distance exponents $(0.5,1,1.5$ and 2$)$, but the best fit was obtained with the $20 \mathrm{~km}$ threshold. These results are available upon request.
} 
distance of less than $20 \mathrm{~km}$ between two municipalities and 0 otherwise, where $n_{i}=$ the number of neighbours of municipality $i$. Note that this procedure is equivalent to computing the neighbours' tax increase as a weighted average of the tax rate increases of all the municipalities defined as 'neighbours'.

\subsection{Econometrics}

Endogeneity. The first econometric problem we found, which is widely mentioned in the literature on the estimation of popularity functions (see for example Paldam, 1997, Stults and Winters, 2002) and also in some papers testing the comparative voting hypothesis (Revelli, 2002), consists of the finding that the tax increase in equation (2) can not be assumed to be strictly exogenous. The reason for the endogeneity is that there may be shocks to the local government's popularity (included in the error term $\varepsilon_{i, t}$ ) that are correlated with the tax increase. For example, consider a local government seeking reelection at a time of low popularity that decides to recover the support of the citizens by cutting the local tax rate. On the other hand, consider the situation of a very confident local government (either because the citizens of this municipality have a very marked preference for the ideology of this party or because the party has suffered a huge positive popularity shock at regional or national levels). This government team can raise the local tax and still expect to be re-elected. In previous papers, Solé-Ollé (2003 and 2005) explicitly acknowledge that incumbent Spanish governments differentiate their fiscal policies according to their perceived popularity, measured by the margin of victory obtained in the previous election. In this paper, we do not attempt to estimate a comprehensive political-economy model that includes both a vote equation and a tax setting reaction equation, but instead follow the procedure used by Revelli (2002) and adopt an Instrumental Variables approach in order to solve the tax increase endogeneity in the vote equation.

We found some difficulties in obtaining valid instruments for the tax rate increase, although this is a general problem in this kind of studies (see Stults and Winters, 2002). Note that some of the variables that may help to explain effective property tax rate increases are already included in the vote equation. For example, we could have tried to use the margin of victory in the previous election, but this variable is very much the same (at least in our sample) as the previous vote share (included in the equation) and is, therefore, inappropriate as an instrument. It should also be noted that the financial 
variables that seem to be exogenous determinants of local tax rates in the Spanish case (e.g., intergovernmental transfers, see Solé-Ollé, 2003) are not included in our database. Moreover, some of the variables present in our database are correlated with the residuals and are not valid instruments. This is the case of the a dummy indicating if a property value reassessment took place during the four-year term, the number of years since the last property reassessment at the beginning of the term, and the growth in assessed value per capita during the four-year term. In none of these cases did the Sargan test (Sargan, 1958) allow us to accept the validity of these variables as instruments. There are some explanations for the failure of these variables as instruments. Firstly, these results clearly suggest that although they are carried out by a central government agency, property value reassessments are endogenous, in the sense that only when a local government feels politically safe is it able to accept the risk of such a process (which usually entails increases in tax liabilities). Secondly, the rise in assessed values per capita is also endogenous, because these values tend to rise because of property value reassessments. Thirdly, the number of years since the last reassessment (and number of years squared) is also a determinant of the probability of carrying out a reassessment. Although this variable seems in principle to be exogenous, one would think that if the reassessment has not been carried out previously, it is because the local government is especially vulnerable to popularity shocks.

The only valid instruments we have been able to find are: the increase in the number of homes per capita during the four-year term, the lagged effective property tax rate (i.e., the effective tax rate in the previous election year), the distance between the nominal tax rate and the maximum nominal tax rate allowed by law, and this variable squared ${ }^{24}$.

There are various stories that may be invoked to justify the use of these variables as instruments. The increase in the number of homes per capita leads to an increase in the property tax base that may help to reduce the effective property tax rate. The effective property tax rate increase may rise as its lagged value falls if local governments gradually

\footnotetext{
${ }^{24}$ The lagged effective tax rate was computed by adding the increases in the effective property tax rate that occurred in the following periods to the 1990 nominal tax rate. The lagged effective tax rate and the 'distance between nominal and maximum nominal tax rates' are only slightly correlated (with a correlation coefficient of 0.256). There are two reasons for this result. Firstly, maximum nominal tax rates are not the same for all the municipalities, but grow with population size, and secondly, when a reassessment is carried out effective tax rates tend to peak and, at the same time, nominal tax rates decrease in order to avoid excessive increases in tax liabilities. These two effects compensate for the obvious increase in the effective tax rate that occurs when a municipality decides to rise the nominal tax rate.
} 
adjust the levels of taxation to their desired levels. The relationship between the effective property tax rate increase and the distance between the nominal tax rate and the maximum nominal tax rate allowed by law may be explained by two different effects. On the one hand, if property value reassessments are not carried out, local governments are forced to use the nominal tax rate in order to increase tax liabilities. However, as nominal tax rates are increased year after year, they approach the maximum nominal tax rate allowed, reducing the margin for continuing with these increases in the future. We therefore expect that as the distance between the nominal tax rate and the maximum tax rate diminishes, the local government will pass lower nominal tax increases and, in the absence of a property value reassessment process, these will automatically lead to effective tax increases. On the other hand, the erosion of the margin for increasing the nominal tax rate may force the local government to engage in a property value reassessment process, and it is an empirical regularity that effective property tax rates tend to rise after such a process $^{25}$. Since the two effects have different signs, the relationship between the distance between nominal and maximum tax rate and the increase in the effective tax rate may well be non-linear.We will therefore use both the distance and the distance squared as instruments.

These instruments meet the two conditions that should be demanded of a good instrument - orthogonality with the residuals and correlation with the effective property tax rate increase. Table 1 shows several attempts at estimating the first-stage regressions, including both the 'good' and the 'bad' instruments. Column 1 uses the following as instruments: the lagged effective tax rate $\left(t_{i, t-4}^{e}\right)$, the increase in the number of homes $\left(\Delta h_{i, t-4}\right)$, the distance between the nominal and the maximum tax rate $\left(t_{i, t-4}^{\max }-t_{i, t-4}^{n}\right)$, and the number of years since the last reassessment $\left(a_{i, t-4}\right)$. Column 2 adds the square of these last two variables. Note that the explanatory capacity of these first-stage regressions is substantial, which follows the rule of thumb suggested by Staiger and Stock (1997) that first-stage F-statistics should be higher than ten, and that explanatory capacity improves

\footnotetext{
${ }^{25}$ There are various possible explanations for this increase. Firstly, there is the fact that in Spain, in addition to maximum nominal tax rates, there are also minimum nominal tax rates. It is true that the minimum tax rate is allowed to fall after a property value reassessment, but it is also true that these minimum tax rates must be raised again five years after the reassessment. Secondly, it may be politically advantageous to increase the effective property tax rate after a property value reassessment, although it is not entirely whether this political advantage arises entirely from rational behaviour (as Strumpf, 2002, suggests) or is due to voters' fiscal illusion (Bloom and Ladd, 1982; Ladd, 1991).
} 
when the squared terms are added. However, the value of the Sargan test of overidentifying restrictions is very high. We are not able to reject the null of correlation between the instruments and the error term and we have to conclude that some of these instruments are not valid. Columns 3 and 4 repeat the estimation by excluding the 'years since reassessment' and the 'homes per capita' variables, respectively. When excluding the 'years since reassessment' variable the value of the Sargan test drops abruptly, so we can now accept that the instruments are correct at conventional significance levels. When excluding the variable 'homes per capita' (column 4), we still have problems with the instruments. Finally, if we exclude both variables (column 5) the remaining instruments appear to be valid but the explanatory capacity of the model drops a little. Given that all the instruments of column 3 seem to be valid ${ }^{26}$, we decided to use column 3 as our firststage regression for the IV estimation of the vote equation ${ }^{27}$.

\footnotetext{
${ }^{26}$ One may have a prior suspicion about the validity of the 'homes per capita' instrument. In order to test for this possibility, we use a 'difference-in-Sargan' statistic (Hayashi, 2000), computed as the difference of the Sargan statistics of columns 5 and 3 of Table 1 (excluding and including this instrument). This test is distributed as a $\chi^{2}(\mathrm{~K})$ with $\mathrm{K}=$ loss of over-identifying restrictions. The value of the test is in this case 2.562 , which is clearly lower than a $\chi^{2}(1)$ at conventional significance levels. We therefore have to accept the validity of the 'homes per capita' variable as an instrument.

${ }^{27}$ In Table 2, we have not presented the results obtained when using the reassessment dummy, but the results obtained for this variable indicate that, although its explanatory capacity is substantial, it is clearly correlated with the error term.
} 
Table 2: Instrumental variables estimation: first-stage regression.

Dependent variable: 'effective' property tax increases $\left(\Delta t_{i, t-4}^{e}\right)$

No. obs. $9.397(N=2.799, T=3: 1995,1999 \& 2003$ Elections $)$

\begin{tabular}{|c|c|c|c|c|c|}
\hline Variable & (1) OLS & (2) OLS & (3) OLS & (4) OLS & (5) OLS \\
\hline$t_{i, t-4}^{e}$ & $\begin{array}{c}-0.034 \\
(-5.091)^{* * *}\end{array}$ & $\begin{array}{c}-0.056 \\
(-7.089)^{* * *}\end{array}$ & $\begin{array}{c}-0.051 \\
(-2.601)^{* * *}\end{array}$ & $\begin{array}{c}-0.041 \\
(-6.435)^{* * *}\end{array}$ & $\begin{array}{c}-0.048 \\
(-2.378)^{* * *}\end{array}$ \\
\hline$t_{i, t-4}^{\max }-t_{i, t-4}^{n}$ & $\begin{array}{c}0.096 \\
(2.578)^{* *}\end{array}$ & $\begin{array}{c}-0.734^{* * *} \\
(-2.746)^{*}\end{array}$ & $\begin{array}{c}-0.893 \\
(-3.379)^{* * *}\end{array}$ & $\begin{array}{c}-0.761 \\
(-2.832)^{*}\end{array}$ & $\begin{array}{c}-0.878 \\
(-3.687)^{* * *}\end{array}$ \\
\hline$\left(t_{i, t-4}^{\max }-t_{i, t-4}^{n}\right)^{2}$ & --.-- & $\begin{array}{c}0.985 \\
(3.799)^{* * *}\end{array}$ & $\begin{array}{c}0.810 \\
(3.286)^{* * *}\end{array}$ & $\begin{array}{c}0.965 \\
(3.845)^{* * *}\end{array}$ & $\begin{array}{c}0.977 \\
(3.319)^{* * *}\end{array}$ \\
\hline$a_{i, t-4}$ & $\begin{array}{c}0.010 \\
(6.350)^{* * *}\end{array}$ & $\begin{array}{c}0.049 \\
(9.796)^{* * *}\end{array}$ & --.-- & $\begin{array}{c}0.055 \\
(11.150)^{* * *}\end{array}$ & --.-- \\
\hline$a_{i, t-4}^{2}\left(\times 10^{2}\right)$ & --.-- & $\begin{array}{c}-0.056 \\
(-10.994)^{* * *}\end{array}$ & --.-- & $\begin{array}{c}-0.057 \\
(-11.326)^{* * *}\end{array}$ & --.-- \\
\hline$\Delta h_{i, t-4}$ & $\begin{array}{c}-0.098 \\
(-2.177)^{* * *}\end{array}$ & $\begin{array}{c}-0.125 \\
(-3.281)^{* * *}\end{array}$ & $\begin{array}{c}-0.144 \\
(-5.657)^{* * *}\end{array}$ &.---- &.---- \\
\hline Adjusted $R^{2}$ & 0.107 & 0.147 & 0.110 & 0.135 & 0.087 \\
\hline F-statistic (All instruments) & $44.818^{* * *}$ & $59.181^{* * *}$ & $46.106^{* * *}$ & $55.436^{* * *}$ & $37.211^{* * *}$ \\
\hline F-statistic (Excluded variables) & $18.605^{* * *}$ & $30.535^{* * *}$ & $15.266^{* * *}$ & $27.192^{* * *}$ & $7.291^{* * *}$ \\
\hline Sargan (Instrument validity) & $\begin{array}{l}15.663 \\
{[0.000]}\end{array}$ & $\begin{array}{l}24.351 \\
{[0.000]}\end{array}$ & $\begin{array}{c}7.315 \\
{[0.071]}\end{array}$ & $\begin{array}{l}26.031 \\
{[0.000]}\end{array}$ & $\begin{array}{c}4.870 \\
{[0.093]}\end{array}$ \\
\hline
\end{tabular}

Notes: (1) $t$ statistics are shown in brackets; ${ }^{* *} \& * * *$ significantly different from zero at the $90 \%, 95 \%$ and $99 \%$ levels. (2) Sargan test for instrument validity, distributed as a $\chi^{2}(\mathrm{~K})$ with $\mathrm{K}=$ number of over-identifying restrictions ( $\mathrm{p}$-value in brackets).

Spatially correlated shocks. The other econometric challenge is caused by the fact that the presence of the neighbour's tax increases in the right hand of the vote equation may introduce a bias if the shock to popularity $\left(\varepsilon_{i, t}\right)$ is itself spatially correlated. Let us suppose, for instance, that $\varepsilon_{i, t}$ follows a first order spatial auto-correlation process:

$$
\varepsilon_{i, t}=\rho \cdot \mathrm{W} \varepsilon_{i, t}+\xi_{i, t}
$$

This pattern may be caused, for example, by the omission of relevant economic and political controls that show a spatial pattern from the vote equation. Let us consider, for example, a region hit by a recession (not well controlled by the variables included in the equation) which hurts all the governments. In this case, the OLS coefficient of neighbours' tax increase may be picking not only the 'comparative voting' effects but also the effects of these omitted variables. A common procedure for solving this problem 
is to instrument the neighbour's tax increases (see Revelli, 2002). The available instruments are the same as for the own tax increases: the neighbour's lagged effective tax rate, the neighbour's distance between nominal and maximum tax rates, and the neighbour's 'homes per capita'. However, in our case, it will not be necessary to instrument this variable. We reached this conclusion after performing two tests. First, we tested for spatial auto-correlation in the error term of the vote equation using the Moran's I test (Moran, 1948). The test was also computed with the standardised $20 \mathrm{~km}$ weights matrix introduced above. In no case can the null hypothesis of an absence of spatial autocorrelation be rejected. We also performed a Hausman endogeneity test (Hausman, 1978), by comparing the coefficient vector obtained by instrumenting only the municipality's tax increase and that obtained when also instrumenting the neighbours' tax rates ${ }^{28}$. The value of the test is very low, due to the fact that the coefficient estimates are similar in both cases, and we have to conclude that the neighbours' tax increases can be considered exogenous.

\section{Results}

The parameter estimates of the basic vote equation (2) are shown in Table 3. Table 4 shows the results of the estimation of vote equation that includes the interactions of tax increases with the government type dummies. In both tables, the dependent variable is the vote share of all the parties in the local government team ${ }^{29}$. In all the cases the explanatory capacity of the model is quite good.

Basic results. As can be seen in the first column of Table 3, the coefficient of the municipality's tax increase variable is not statistically significant when the equation is estimated by Ordinary Least Squares (OLS). Note that although the sign of the coefficient was what expected, its value is quite low. Nevertheless, the coefficient of the neighbours'

\footnotetext{
${ }^{28}$ Hausman-Wu tests compare the coefficients of an efficient estimator (usually OLS) and an inefficient but consistent estimator (IV). The test statistic is distributed as an $\chi^{2}(\mathrm{~K})$ with $\mathrm{K}=$ number of regressors being tested for endogeneity. The test can also be used to test for the endogeneity of a subset of regressors (in our case, the neighbours' tax rates). The test is performed as before, as the difference between the two vectors of coefficients. In this case, however, the fully efficient estimator is the one that treats the municipality's tax increases as endogenous but the neighbours' tax increases as exogenous, and the inefficient but consistent estimator is the one that treats both variables as exogenous.

${ }^{29}$ The results were replicated with the vote share of the party of the mayor as the dependent variable. We will comment on these additional results at the end of this section.
} 
tax increase is positive and statistically significant at the $95 \%$ level. These results suggest that the equation might need to be estimated by Instrumental Variables (IV). The results of the IV estimation are shown in the second and third columns of Table 2 . In the second column, only the municipality's own tax increase has been instrumented, while in the third the neighbours' tax increase has also been instrumented. The results of the Moran's I statistic allow us to reject the presence of spatial auto-correlation in the error term, and the Hausman test suggests that the neighbours' tax increase variable is not correlated with the error term. This suggests that it is not necessary to instrument this variable and that we can concentrate on the results of column 2. As we mentioned in the previous section, we experimented with many instruments for the municipality's tax increase, but only a subset of them could be considered exogenous. We present the results when using all the appropriate instruments simultaneously (i.e., growth in number of homes per capita, lagged effective tax rate, and distance between nominal and maximum tax rates, and this variable squared). The results of Table 2 showed that these variables explain a substantial portion of the changes in effective property tax rates. Since some of our instruments are constructed with lagged variables, it seems necessary to test for serial correlation in the residuals of the vote equation. The Arellano and Bond (1991) AR(1) test (at the bottom of the table) indicates that there is no serial correlation, which confirms the reliability of our instruments. 
Table 3: Effects of property tax increases on the vote share $\left(v_{i, v}\right)$ of Spanish local governments. Basic results. No. obs. $=9.397(N=2.799, T=3: 1995,1999$ \& 2003 Elections $)$

\begin{tabular}{|c|c|c|c|c|c|c|}
\hline Variable & (1) OLS & (2) IV & (3) IV & (4) IV & (5) IV & (6) IV \\
\hline \multicolumn{7}{|c|}{ i.- Property tax rates } \\
\hline$\Delta t_{i, t-4}^{e}$ & $\begin{array}{c}-0.034 \\
(-0.522)\end{array}$ & ${ }^{-0.084}$ & $\begin{array}{c}-0.078 \\
(-5.741)^{* * *}\end{array}$ & $\begin{array}{c}-0.028 \\
(-0.604)\end{array}$ & $\begin{array}{c}-0.016 \\
(-0.874)\end{array}$ & $\begin{array}{c}-0.085 \\
(-4.784)^{* * *}\end{array}$ \\
\hline$\Delta \mathrm{W} t_{i, t-4}^{e}$ & $\begin{array}{l}0.061 \\
(2.101)^{* *}\end{array}$ & $(3.308)^{* * *}$ & $\begin{array}{l}0.059 \\
(2.974)^{* * *}\end{array}$ & $\begin{array}{c}0.044 \\
(1.602)\end{array}$ & $\begin{array}{l}0.052 \\
(3.643)^{* * *}\end{array}$ & $(3.422)^{* * *}$ \\
\hline \multicolumn{7}{|c|}{ ii.- Controls: economic } \\
\hline$\Delta u_{i, t-4}$ & $\begin{array}{c}-0.023 \\
(-0.404)\end{array}$ & $\begin{array}{c}-0.026 \\
(-0.310)\end{array}$ & $\begin{array}{c}-0.022 \\
(-0.651)\end{array}$ & $\begin{array}{c}-0.011 \\
(-0.152)\end{array}$ & $\begin{array}{c}-0.030 \\
(-1.584)\end{array}$ &.---- \\
\hline$\Delta \mathrm{W} u_{i, t-4}$ & $\begin{array}{c}0.069 \\
(2.462)^{* *}\end{array}$ & $\begin{array}{c}0.073 \\
(2.600)^{* * *}\end{array}$ & $\begin{array}{l}0.070 \\
(2.541)^{* * *}\end{array}$ & $\begin{array}{c}-0.007 \\
(-0.001)\end{array}$ & $\begin{array}{c}-0.022 \\
(-1.054)\end{array}$ &.---- \\
\hline$\Delta n_{i, t-4}$ & $\begin{array}{c}0.043 \\
(1.422)\end{array}$ & $\begin{array}{c}0.043 \\
(1.569)\end{array}$ & $\begin{array}{c}0.044 \\
(1.350)\end{array}$ & $\begin{array}{c}0.040 \\
(0.645)\end{array}$ & $\begin{array}{c}0.054 \\
(1.554)\end{array}$ &.---- \\
\hline$\Delta \mathrm{W} n_{i, t-4}$ & $\begin{array}{c}-0.016 \\
(-1.369)\end{array}$ & $\begin{array}{c}-0.026 \\
(-1.236)\end{array}$ & $\begin{array}{c}-0.031 \\
(-0.874)\end{array}$ & $\begin{array}{c}-0.133 \\
(-0.841)\end{array}$ & $\begin{array}{c}-0.021 \\
(-1.210)\end{array}$ &.---- \\
\hline \multicolumn{7}{|c|}{ iii.- Controls: political } \\
\hline$v_{i, t-4}$ & $\begin{array}{c}0.663 \\
(15.820)^{* * *}\end{array}$ & $\begin{array}{c}0.666 \\
(15.872)^{* * *}\end{array}$ & $\begin{array}{c}0.687 \\
(14.981)^{* * *}\end{array}$ & $\begin{array}{c}0.682 \\
(16.572)^{* * *}\end{array}$ &.---- & $\begin{array}{c}0.665 \\
(15.863)^{* * *}\end{array}$ \\
\hline $\bar{v}_{i}$ & $\begin{array}{c}0.186 \\
(5.700)^{* * *}\end{array}$ & $\begin{array}{c}0.185 \\
(5.667)^{* * * *}\end{array}$ & $\begin{array}{c}0.180 \\
(5.741)^{* * * *}\end{array}$ & $\begin{array}{c}0.187 \\
(6.082)^{* * *}\end{array}$ &.---- & $\begin{array}{c}0.186 \\
(5.720)^{* * *}\end{array}$ \\
\hline $\mathrm{COA}_{i, t}$ & $\begin{array}{c}-0.045 \\
(-7.061)^{* *}\end{array}$ & $\begin{array}{c}-0.048 \\
(-7.344)^{* *}\end{array}$ & ${ }^{-0.038}(-8.647)^{* * *}$ & ${ }^{-0.047}(-7.215)^{* * *}$ & $--\cdot--$ & $\begin{array}{c}-0.046 \\
(-7.100)^{* * *}\end{array}$ \\
\hline $\mathrm{NEW}_{i}$ & $\begin{array}{c}0.032 \\
(7.062)^{* * *}\end{array}$ & $\begin{array}{c}0.046 \\
(4.548)^{* * *}\end{array}$ & $\begin{array}{l}0.051 \\
(2.674)^{* * *}\end{array}$ & $(3.966)^{* * *}$ & --.-- & $\begin{array}{c}0.045 \\
(4.486)^{* * *}\end{array}$ \\
\hline Party $\times$ Region $\times$ Time effects & YES & YES & YES & $\mathrm{NO}$ & YES & YES \\
\hline Adjusted $R^{2}$ & 0.774 & 0.775 & 0.754 & 0.152 & 0.172 & 0.057 \\
\hline Breusch-Pagan (Heterosk.) & 0.889 & 1.221 & 0.868 & 0.968 & 0.667 & 0.578 \\
\hline Sargan (Instrument validity) &.---- & $\begin{array}{c}4.870 \\
{[0.093]}\end{array}$ & $\begin{array}{l}10.521 \\
{[0.072]}\end{array}$ & $\begin{array}{c}4.741 \\
{[0.097]}\end{array}$ & $\begin{array}{c}6.210 \\
{[0.043]}\end{array}$ & $\begin{array}{c}5.110 \\
{[0.068]}\end{array}$ \\
\hline Hausman (Endogeneity) &.---- &.---- & $\begin{array}{c}0.213 \\
{[0.000]}\end{array}$ &.---- &.---- &.---- \\
\hline Moran's I (Spatial error corr.) & 0.125 & 0.098 & 0.101 & 0.114 & 0.014 & 1.221 \\
\hline AR (1) (Serial error corr.) & 0.541 & 0.301 & 0.156 & 0.621 & 0.504 & 0.741 \\
\hline Wald (Economic controls) & 7.25 & 7.33 & 7.54 & 5.69 & 3.98 & $--\cdot--$ \\
\hline Wald (Political controls) & $90.66^{* * *}$ & $47.65^{* * *}$ & $51.36^{* * *}$ & $42.51^{* * *}$ &.---- & $56.14^{* * *}$ \\
\hline Wald $($ Party $\times$ Region $\times$ Time $)$ & $902.38^{* * *}$ & $921.12^{* * *}$ & $900.54^{* * *}$ &.---- & $914.51^{* * *}$ & $936.47^{* * *}$ \\
\hline
\end{tabular}

Notes: (1) $t$ statistics are show in brackets; $* * * \& * * *$ significantly different from zero at the $90 \%, 95 \%$ and $99 \%$ levels. (2)IV = instrumental variables estimation. (3) Breusch-Pagan test for the presence of heteroskedasticity. (4) Sargan test for instrument validity, distributed as a $\chi^{2}(\mathrm{~K})$ with $\mathrm{K}=$ number of overidentifying restrictions (p-value in brackets); instruments used: increase in homes per capita, lagged effective tax rate, lagged distance to top allowed tax rates, and this last variable squared. (5) Moran's I test for spatial error correlation, distributed as a $\mathrm{N}(0,1)$. (6) Hausman (1978) test of endogeneity of neighbour's tax increase, distributed as a $\chi^{2}(1)$ (p-value in brackets). (7) Arellano and Bond (1991) panel $\mathrm{AR}(1)$ test. (8) Wald test of the joint significance of different groups of variables. 
The results of the IV estimation confirm that the municipality's own tax increases have an adverse impact on the vote share. An increase of 1 point in the property tax rate (i.e., an additional $1 \%$ on the assessed property value) reduces the vote share of the parties in the local government by a $8.4 \%$. This is not a very large impact, but neither is it negligible. From Table 1, we can see that the average tax increase during one four-year period is approximately $0.15 \%$. This means that the government of the average municipality loses $1.26 \%$ of its vote because of tax increases. The results regarding the neighbours' tax increases mirror those of the municipality's own tax increases. The sign in this case is always positive and the coefficient is statistically significant. The magnitude of the coefficient is only slightly lower (in absolute value) than that of the municipality's own tax increase. What therefore really has an impact on the vote for the government is a 'relative' property tax increase. If a local government enacts a property tax increase of a similar magnitude to the one enacted by other governments, the vote loss need not be very high. The 'comparative voting' hypothesis is therefore confirmed by our results.

The results shown in Table 3 regarding the control variables also merit some comments. Firstly, the economic controls have the expected sign (i.e., increases in unemployment relative to the neighbourhood are punished, while increases in the relative population size are rewarded), although the coefficients are not generally statistically significant. Secondly, the coefficient of the lagged vote share is positive and significant, indicating the persistence of popularity shocks or 'incumbency advantage'. Thirdly, the average vote share is also positive and highly significant. Moreover, the coefficient of this variable is quite high, suggesting a high degree of voter preseverance with the different ideological options. Fourthly, the coalition dummy (COA) is statistically significant and the coefficient is negative, meaning that -other things being equal- coalitions are punished in elections, obtaining a vote share that is $3-4 \%$ lower. This means that voters find that some traits of coalition governments are unattractive (e.g. problems requiring collective action). Fifthly, the first term dummy is also statistically significant and its effect is positive. This means that voters give some confidence to first term governments, which have a $3-5 \%$ bonus compared to older governments. Sixthly, the Party $\times$ Region $\times$ Time effects are statistically significant (see the Wald test at the bottom of the table). This should be interpreted as evidence of the influence of national politics on municipal elections. When a party suffers a popularity shock at national or regional level, its vote share in a given municipality is also reduced. These results are consistent with those 
obtained by Revelli (2002) for the UK. In our case, however, the relevance of national politics does not prevent local tax increases also having some impact on the voting results. In fact, controlling for national political influences (and for other political factors) becomes essential in order to insure that the estimated coefficients for the tax increase variables are unbiased. In Columns 4, 5 and 6 of Table 3, we check whether or not the significant effect of tax increases on the vote are conditioned by the inclusion in the equation of the different control variables. Column 4 excludes the Party $\times$ Region $\times$ Time effects, column 5 excludes the other political control variables, and column 6 excludes the economic controls. In our case, the statistically significant effect is guaranteed only when the political control variables are included. These results are virtually unaffected by the economic control variables. 
Table 4: Effects of property tax increases on the vote share $\left(v_{i, t}\right)$ of Spanish local Governments. Political interactions. No. obs. $=9.397(N=2.799, T=3: 1995,1999 \& 2003$ Elections $)$

\begin{tabular}{|c|c|c|c|c|c|c|}
\hline Variable & (1) OLS & (2) OLS & (3) OLS & (4) IV & (5) IV & (6) IV \\
\hline$\Delta t_{i, t-4}^{e}$ & $\begin{array}{c}-0.025 \\
(-0.569)\end{array}$ & $\begin{array}{c}-0.015 \\
(-0.367)\end{array}$ & $\begin{array}{c}-0.018 \\
(-0.621)\end{array}$ & $\begin{array}{c}-0.062 \\
(-2.359)^{* * *}\end{array}$ & $\begin{array}{l}-0.043 \\
(-2.256)^{* *}\end{array}$ & $\begin{array}{c}-0.044 \\
(-2.365)^{* *}\end{array}$ \\
\hline$\Delta \mathrm{W} t_{i, t-4}^{e}$ & $\begin{array}{c}0.017 \\
(2.158)^{* *}\end{array}$ & $\begin{array}{c}0.014 \\
(2.236)^{* *}\end{array}$ & $\begin{array}{l}0.016 \\
(2.320)^{* *}\end{array}$ & $\begin{array}{c}0.042 \\
(3.701)^{* * *}\end{array}$ & $\begin{array}{c}0.037 \\
(2.320)^{* *}\end{array}$ & $\begin{array}{c}0.038 \\
(2.021)^{* *}\end{array}$ \\
\hline$\Delta t_{i, t-4}^{e} \times \mathrm{RIGHT}_{i, t}$ & $\begin{array}{l}-0.042 \\
(-2.013)^{* *}\end{array}$ & $\begin{array}{c}-0.047 \\
(-1.985)^{* *}\end{array}$ & $\begin{array}{l}-0.038 \\
(-2.001)^{* *}\end{array}$ & $(-0.562)^{* * *}$ & $\begin{array}{c}-0.051 \\
(-3.025)^{* * *}\end{array}$ & $\begin{array}{c}-0.056 \\
(-2.754)^{* * *}\end{array}$ \\
\hline$\Delta \mathrm{W} t_{i, t-4}^{e} \times \mathrm{RIGHT}_{i, t}$ & $\begin{array}{l}0.026 \\
(2.641)^{* * *}\end{array}$ & $\begin{array}{l}0.023 \\
(2.263)^{* * *}\end{array}$ & $\begin{array}{l}0.024 \\
(2.206)^{* * *}\end{array}$ & $\begin{array}{l}0.055 \\
(3.001)^{* * *}\end{array}$ & $\begin{array}{l}0.047 \\
(2.305)^{* * *}\end{array}$ & $\begin{array}{l}0.044 \\
(2.884)^{* * *}\end{array}$ \\
\hline$\Delta t_{i, t-4}^{e} \times \mathrm{COA}_{i, t}$ & --.-- & $\begin{array}{c}-0.015 \\
(-1.786)^{*}\end{array}$ & $\begin{array}{c}-0.018 \\
(-1.696)^{*}\end{array}$ &.---- & ${ }^{-0.067}$ & $\begin{array}{l}-0.045 \\
(-3.021)^{* * *}\end{array}$ \\
\hline$\Delta \mathrm{Wt}_{i, t-4}^{e} \times \mathrm{COA}_{i, t}$ & --.-- & $(3.559)^{* * *}$ & $\begin{array}{l}0.041^{* * *} \\
(3.101)^{\prime *}\end{array}$ &.---- & $\begin{array}{l}0.040 \\
(3.965)^{* * *}\end{array}$ & $\begin{array}{l}0.034 \\
(3.364)^{* * *}\end{array}$ \\
\hline$\Delta t_{i, t-4}^{e} \times \mathrm{NEW}_{i, t}$ &.---- &.---- & $\begin{array}{l}0.008 \\
(1.362)\end{array}$ &.---- &.---- & $\begin{array}{c}0.012 \\
(1.745)^{*}\end{array}$ \\
\hline$\Delta \mathrm{W} t_{i, t-4}^{e} \times \mathrm{NEW}_{i, t}$ &.---- &.---- & $\begin{array}{c}-0.009 \\
(-1.446)\end{array}$ &.---- &.---- & $\begin{array}{c}-0.014 \\
(-1.320)\end{array}$ \\
\hline Economic controls & YES & YES & YES & YES & YES & YES \\
\hline Political controls & YES & YES & YES & YES & YES & YES \\
\hline Party $\times$ Region $\times$ Time effects & YES & YES & YES & YES & YES & YES \\
\hline Adjusted $R^{2}$ & 0.712 & 0.735 & 0.728 & 0.732 & 0.741 & 0.735 \\
\hline Breusch-Pagan (Heterosk.) & 0.885 & 0.956 & 0.960 & 0.985 & 1.335 & 1.241 \\
\hline Sargan (Instrument validity) &.---- &.---- &.---- & $\begin{array}{c}7.804 \\
{[0.095]}\end{array}$ & $\begin{array}{c}7.594 \\
{[0.013]}\end{array}$ & $\begin{array}{c}7.822 \\
{[0.091]}\end{array}$ \\
\hline Moran's I (Spatial error corr.) & 0.226 & 0.125 & 0.326 & 0.185 & 0.109 & 0.952 \\
\hline AR (1) (Serial error corr.) & 0.741 & 0.446 & 0.269 & 0.774 & 0.553 & 0.651 \\
\hline Wald (Economic controls) & 5.46 & 7.99 & 7.21 & 5.24 & 7.85 & 8.00 \\
\hline Wald (Political controls) & $91.10^{* * *}$ & $93.00^{* * *}$ & $59.10^{* * *}$ & $91.21^{* * *}$ & $92.33^{* * *}$ & $58.01^{* * *}$ \\
\hline Wald $($ Party $\times$ Region $\times$ Time $)$ & $914.10^{* * *}$ & $977.62^{* * *}$ & $1,022.06^{* * *}$ & $921.56^{* * *}$ & $998.21^{* * *}$ & $1,014.15^{* * *}$ \\
\hline
\end{tabular}

Notes: See Table 3.

Interactions. The results allowing for differential effects of tax increases according to political traits of local governments are shown in Table 4. The first three columns show the OLS results and the last three the IV results. The first and the fourth columns show how the effect on the vote share depends on ideology. The coefficient of the tax increase variable (without interaction) shows the result for the base category (LEFT). In order to ascertain the impact of a tax increase in the case of a right-wing government, this 
coefficient must be added to the one for the tax increase interacted with the RIGHT dummy. The OLS results of column 1 show a negative but not significant effect of the municipality's own tax increases for the base category, but a negative and statistically significant effect in the case of right-wing governments. Since we simultaneously expect that OLS results may be biased and that right-wing governments should be more heavily penalised than left-wing ones for tax increases, these results do provide some evidence for the effect of taxation on the vote ${ }^{30}$. The OLS results also show that neighbours' tax increases have a statistically positive impact on votes for all types of governments, but that the impact is higher in the case of right-wing governments. The difference when estimating the equation by IV (column 4) is that the impact of the municipality's own taxes on the vote is now also statistically significant, and that the interaction coefficients are higher than in the OLS case. The results regarding the impact of ideology are maintained when allowing for additional interactions. We should conclude that the results seem to confirm our hypothesis that left-wingers are less heavily punished for tax increases than right-wingers. For a $1 \%$ increase in the property tax rate, right-wingers lose $9 \%$ of their vote share and left-wingers only $4.4 \%$. In the case of neighbours' tax increases, left-wingers are rewarded less $(3.8 \%)$ than right-wingers $(8.2 \%)$. The results therefore suggest that in the case of parties on the left, voters tend to use less (relative) tax increases as a key to judging the performance of the incumbent, and that this has more or less the same effect on the municipality's own and on neighbours' tax increases.

The second and fifth columns of Table 4 add an interaction of the tax increase to the coalition dummy (COA). The results show that the coefficient of this interaction is negative and statistically significant in both the OLS and the IV cases, although the size of the coefficient is higher in the IV case. These results mean that the effect of a tax increase on the vote is stronger for coalitions than for majority governments. For a $1 \%$ increase in the property tax rate, majorities lose $4.4 \%$ of the vote, but coalitions lose $8.9 \%$. These results are not consistent with the 'clarity of responsibility' hypothesis that states that coalitions are held more accountable than majorities. There is no big surprise in confirming that this hypothesis does not hold. After all, many papers analysing economic

\footnotetext{
${ }^{30}$ The endogeneity problem can be considered as as an omitted variable, showing an unmeasurable popularity shock of the incumbent. If tax increases and popularity are positively correlated, then the omission of popularity biases the OLS coefficient for the own tax increase towards zero. If we allow for a differential impact of tax increases on the vote, both coefficients (left and right) will be biased towards zero, but since the impact is much higher in one of the categories (right), we will still be able to find a statistically significant effect of taxes on the vote for this category (Stults and Winters, 2002).
} 
voting in an international context rejected it, at least in its basic version (see for example Anderson, 2000, Nadeau et al., 2002). However, in the Spanish case coalitions are not only held less accountable than majorities but the vote losses of a coalition are also very high. It seems that voters have no major problems in assigning responsibility for taxation in the Spanish municipalities. When they encounter some uncertainty regarding which party is responsible for the tax increase they simply decide to punish all the members of the coalition. The fact that the punishment is so heavy may be explained by Spanish electors' lack of confidence in government coalitions which often face collective action problems that make them be more profligate in passing new spending increases that benefit the various coalition partners. This lack of confidence in coalitions can be confirmed by the results of the COA dummy in the vote equation (see Table 2$)^{31}$. Note that the coefficient is always negative and statistically significant. Controlling for all the other influences, a coalition always loses votes relative to a majority. Finally, note also that as in the case of ideology, these results also extend to the effect of neighbour's tax increases, which generate a $3.8 \%$ increase in the vote for a majority, and a $7.2 \%$ increase in the vote of a coalition.

The third and sixth columns of Table 4 add an interaction between the tax increase and the dummy indicating the government is in the first four-year term (NEW). The coefficient is positive but only statistically significant at the $90 \%$ level in the IV case. This means that we have found some evidence that governments are less heavily punished for tax increases during their first term. This may be due to the fact that first term governments have more credibility regarding the possible uses of these additional revenues. In subsequent terms of office, this confidence has been eroded. Voters no longer believe that their money will be used efficiently. Note also that neighbours tax increases have a lower impact on the vote in the case of new governments.

Additional results. In order to check the robustness of our results, we re-estimate the vote equation (both in its basic version and with interactions) making some changes in the definition of the dependent variable and the tax increase. In order to save space, these

\footnotetext{
${ }^{31}$ Although coalitions are the reflection of a highly pluralistic system, this benefit has to be weighted against their decision-making difficulties. Gridlock and collective action problems are not rare in municipal coalitions, and their consequences tend to be perceived as a problem by citizens. The increase in spending in Spanish municipalities due to lack of action, sometimes leading to more taxes and sometimes to deficit finance has been documented by different papers (see Solé-Ollé, 2003 and 2005).
} 
results are not presented here but are only summarised. Firstly, we re-estimate the vote equation using the vote share of the party of the mayor (instead of the vote share of all the parties in the government). The basic results remain qualitatively unaltered. The municipality's own tax increases reduce the vote for the mayor's party by $5 \%$ (it should be recalled that this number was a $8.4 \%$ for all the parties), and neighbours' tax increases increase the vote for the mayor by a $3.7 \%$ (6.2\% beforehand). The results when political interactions are included are also more or less the same. The party of the mayor is also punished more when it is right-wing and when is a coalition, and less when is in its first term of office. Secondly, we re-estimate the vote equation, computing the tax increase during the two years preceding the election instead of using the full four-year period. The results are qualitatively the same, although the coefficients are higher. Now the parties in the government lose $11.5 \%$ of the vote when they raise the property tax rate, and gain $7.5 \%$ of the vote when the tax rate is raised by their neighbours. We also estimated the vote equation simultaneously including the tax increase in the first two years of the term, and the tax increase in the last two years. The results suggest that the municipality's own (neighbours') tax increases always have a negative (positive) impact on the vote, although the impact is much higher in the second part of the term. We can conclude, therefore, that the results presented in the paper are robust to these changes in the definition of the dependent variable and the tax increase.

\section{Conclusion}

We have tested whether or not increases in the property tax rate entail electoral costs for local governments. Results using a database of nearly 3,000 Spanish municipalities and analysing three local elections (1995, 1999 and 2003) suggest that these costs are statistically significant and not negligible. However, the electoral costs of tax increases are conditional on neighbours' tax policy, since voters only seem to punish only tax increases that are bigger than the ones enacted in other municipalities. We interpret this result as evidence of 'comparative voting behaviour' and conclude, therefore, that the main necessary condition for 'yardstick competition' to arise is fulfilled in the Spanish case. These results complement those ones by Solé-Ollé (2003), which were for a small set of Spanish municipalities. In that paper, the author finds that municipalities tend to mimic the property and vehicle tax rates set in the neighbourhood. It would be interesting 
to replicate the results obtained by Solé-Ollé (2003) with the very large database we use in this paper. This is not at present possible, since the database we use does not include many of the variables needed to estimate tax reaction functions accurately (e.g., intergovernmental transfers). This task is left for future work. 


\section{References}

Alesina, A. and Rosenthal, H. (1995): Partisan politics, divided government, and the economy. Cambridge University Press, New York.

Anderson, C.J. (1995): "The dynamics of public support for coalition governments". Comparative Political Studies 28(3), 350-383.

Anderson, C.J. (2000): "Economic voting and political context: a comparative perspective”. Electoral Studies 19, 151-170.

Anselin, L. (1988): Spatial Econometrics: Methods and models. Kluewer Academic Publishers. Dordrecht.

Arellano, M. and Bond, S. (1991): "Some Tests of Specification for Panel Data: Monte Carlo Evidence and an Application to Employment Equations". Review of Economic Studies 58, 277-297.

Besley, T. and Case, A. (1995): "Incumbent behaviour: vote-seeking, tax-setting, and yardstick competition". American Economic Review 85, 25-44.

Besley, T. and Smart, M. (2001): "Electoral accountability and competition among governments". Unpublished manuscript, London School of Economics.

Bordignon, M., Revelli, F., and F. Cerniglia (2003): "In search of yardstick competition: a spatial analysis of Italian municipality property tax setting”. Journal of Urban Economics 54, 199-217.

Bordignon, M., Revelli, F., and F. Cerniglia (2004): "Yardstick competition in intergovernmental relationships: theory and empirical predictions," Economics Letters, forthcoming.

Bloom, H. and Ladd, H.F. (1982): "Property tax revaluation and tax levy growth". Journal of Urban Economics 11, 73-84.

Brett, C. and Pinkse, J. (2000): "The determinants of municipal tax rates in British Columbia”. Canadian Journal of Economics 33, 695-714.

Brooks, J.W. and Prysby, Ch.L. (1992): Political behavior and the local context. Praeger, New York.

Brueckner, J. and Saavedra, L.A. (2001): "Do local governments engage in strategic property tax competition". National Tax Journal 54, 203-229

Buettner, T. (2001): "Local business taxation and competition for capital. The choice of the tax rate". Regional Science and Urban Economics 32, 215-246.

Colomer, J.M. (1995): “España y Portugal”. In Colomer, J.M. (ed.): La política en Europa: introducción a las instituciones de quince países. Ariel, Barcelona.

Diputación de Barcelona (several years): SIEM, Servei d'Informació Econòmica Municipal. 
Feld, L., Josselin, J., and Rocaboy, Y. (2001): "Yardstick competition: a theoretical model and an empirical analysis for French regions". Paper presented at the $56^{\text {th }}$ IIPF Conference, Seville, Spain.

Ferejohn, J. (1986): “Incumbent performance and electoral control”. Public Choice 50, 5-25.

Gibson, J. (1988): "Rate increases and local elections: a different approach and a different conclusion". Policy and Politics 16, 197-208.

Gibson, J. and Steward, J. (1992): "Poll tax, rates and local elections". Political Studies 40, 516-531.

Hansen, S.B. (1983): The politics of taxation: revenue without representation, Praeger, New York.

Hausman, J. (1978): "Specification tests in econometrics". Econometrica 46(3), 12511271.

Hayashi, F. (2000): Econometrics, $1^{\text {st }}$ ed . Princeton University Press, Princeton, New Jersey.

Heyndels, B. and Vuchelen, J. (1998): “Tax Mimicking among Belgian Municipalities". National Tax Journal, 51(1), 89-102.

Kone, S.L. and Winters, R.F. (1983): "Taxes and voting: electoral retribution in the American States". The Journal of Politics 55, 22-40.

Ladd, H.F. (1991): "Property tax revaluation and tax levy growth revisited". Journal of Urban Economics 30, 83-99.

Landon, S. and Ryan, D.L. (1997): "The political costs of taxes and government spending". Canadian Journal of Economics 30(1), 85-111.

Lowry, R.C., Alt, J.E. and Ferree, K.E. (1998): "Fiscal policy outcomes and electoral accountability in American States". American Political Science Review 92, 759774.

Magre, J. (1998): L’Alcalde a Catalunya. Col.lecció Punt a la i, Fundació Jaume Bofill, Barcelona.

Molas, I. and Bartomeus, O. (1998): "Estructura de la competencia política a Catalunya". Working Paper 138, Institut de Ciències Polítiques i Socials, Barcelona.

Moran, P. (1948): "The interpretation of statistical maps". Journal of the Royal Statistical Society B 10, 243-251.

Nadeau, R., Niemi, R.G. and Yoshinaka, A. (2002): “A cross-national analysis of economic voting: taking into account of the political context across time and nations". Electoral Studies 21, 403-423. 
Niemi, R.G., Stanley, H.W. and Vogel, R.J. (1995): "State economies and State taxes: do voters hold governors accountable?". American Journal of Political Science 39, 936-957.

Paldam, M. (1997): "Political business cycles". In D. Mueller (ed.): Perspectives on public choice: a handbook. Cambridge University Press, Cambridge.

Peltzman, S. (1992): "Voters as fiscal conservatives". Quarterly Journal of Economics $107,327-361$.

Pomper, G. (1968 and 1976): Elections in America: Control and influence in American politics. Dodd, Mead., New York.

Powell, G.B. and Whitten, G. (1993): “A cross-national analysis of economic voting: taking account of the political context". American Journal of Political Science. 37, 391-414.

Rallings, C. and Thrasher, M. (1997): Local elections in Britain. Routledge, London.

Revelli, F. (2001): "Spatial patterns in local taxation: tax mimicking or error mimicking?". Applied Economics 33, 1101-1107.

Revelli, F. (2002): "Local taxes, national politics and spatial interactions in English district election results". European Journal of Political Economy 18, 281-299.

Rogoff, K. (1990): "Equilibrium political budget cycles". American Economic Review $80,21-36$.

Royed, T.J., Leyden, K.M. and Borrelli, S.A. (2000): "Is 'clarity of responsibility' important for economic voting? Revisiting the Powell and Whitten's Hypothesis", British Journal of Political Science 30, 669-698.

Salmon, P. (1987): "Decentralization as an incentive scheme". Oxford Review of Economic Policy 3, 24-43.

Sargan, J. (1958): "The estimation of economic relationship using instrumental variables". Econometrica 26(3), 393-415.

Shleifer, A. (1985): “A theory of yardstick competition". Rand Journal of Economics $16,319-327$.

Solé-Ollé, A. (2003): "Electoral accountability and tax mimicking: the effects of electoral margins, coalition government, and ideology". European Journal of Political Economy 19, 685-713.

Solé-Ollé, A. (2005): "The Effects of Party Competition on Budget Outcomes: Empirical Evidence from Local Governments in Spain". Public Choice (forthcoming).

Sotillos, I. (1997): El comportamiento electoral municipal español, 1979-85. Centro de Investigaciones Sociológicas, Madrid. 
Staiger, D. and Stock, J.H. (1997): "Instrumental variables estimation with weak instruments”. Econometrica 65(3), 393-415.

Strumpf, K. (2002): "Infrequent assessments distort property taxes: theory and evidence". Journal of Urban Economics 46, 169-199.

Stults, B. and Winters, R.F. (2002): "The political economy of taxes and the vote". Paper presented at the 2002 Midwest Political Science Association meetings.

Turett, S. (1971): “The vulnerability of American governors: 1900-1969”. Midwest Journal of Political Science 15, 108-132.

Veiga, J. and Veiga, L.G. (2004): "Popularity functions, partisan effects, and support in Parliament". Economics and Politics 16(1), 101-115.

Vermeier, J. and Heyndels, B. (20004): "The electoral cost of tax policy in Flemish municipalities". Paper presented at the 2004 Public Choice Conference in Berlin.

Wilkin, S., Haller, B., and Norpoth, H. (1997): "From Argentina to Zambia: a worldwide test of economic voting". Electoral Studies 16, 301-316.

Wassmer, R.W. (1993): "Property taxation, property base, and property value. An empirical test of the New View". National Tax Journal 46(2), 135-160.

Wrede, M. (2001): "Yardstick competition to tame the Leviathan". European Journal of Political Economy 17, 705-711. 


\section{SÈRIE DE DOCUMENTS DE TREBALL DE L'IEB}

2000

2000/1 - Esteller, A.; Solé, A., "Vertical Income Tax Externalities and Fiscal Interdependence: Evidence from the US"

Publicat a: Regional Science and Urban Economics, 31 (2-3), pàgs. 247-72, 2001.

2000/2 - Castells, A., "The role of intergovernmental finance in achieving diversity and cohesion: the case of Spain"

Publicat a: Environment and Planning C: Government and Policy, 19 (2), pàgs. 189-206, 2001.

2000/3 - Costa, M.T.; Segarra, A. (URV); Viladecans, E., "Pautas de localización de las nuevas empresas y flexibilidad territorial"

Publicat a: Small Business Economics, 22(3-4), pàgs. 265-281, 2004, sota el títol "The location of new firms and the lifecycle of industries".

2000/4 - Costa, M.T.; Duch, N.; Lladós, J. (UAB), "Determinantes de la innovación y efectos sobre la competitividad: el caso de las empresas textiles"

Publicat a: Revista Asturiana de Economía, 20, pàgs. 53-80, 2001.

2000/5 - Solé, A., "Determinantes del gasto público local: necesidades de gasto vs. capacidad fiscal" Publicat a: Revista de Economía Aplicada, 9 (25), pàgs. 115-56, 2001, sota el títol "Determinantes del gasto público local: ¿Necesidades de gasto o capacidad fiscal?"

2000/6 - Barberán, R. (U. de Zaragoza); Bosch, N.; Castells, A.; Espasa, M., "The redistributive power of the Central Government Budget"

2001/1 - Espasa, M., "The territorial redistribution of the EU budget. Empirical evidence at national and regional level"

Publicat a: Enviroment and Planning C: Government and Policy, 19 (5), pàgs. 771-790, 2001, sota el títol "The territorial redistributive power of the EU budget. Empirical evidence at national and regional level"

2001/2 - Viladecans, E., "La concentración territorial de las empresas industriales: un estudio sobre la unidad geográfica de análisis mediante técnicas de econometría espacial"

Publicat a: Papeles de Economía Española, 89/90, pàgs. 308-320, 2001, sota el títol "La concentración territorial de las empresas industriales. Un estudio sobre el tamaño de las empresas y su proximidad geográfica"

2001/3 - Castells, A., "La descentralización de las políticas sociales en el Estado del Bienestar"

2001/4 - Bosch, N.; Pedraja, F. (U. de Extremadura); Suárez-Pandiello, J. (U. de Oviedo), "The influence of Environmental Variables in Measuring the Efficiency of Refuse Collection Services: An Application to the Spanish Municipalities"

Publicat a: Local Government Studies, 26 (3), pàgs. 71-90, 2000.

2001/5 - Solé, A., "Budget spillovers in a metropolitan area: typology and empirical evidence"

2001/6 - Sanromà, E.; Ramos, R. (UB-AQR), "Local human capital and external economies: evidence for Spain"

2001/7 - Leonida, L. (U. Della Calabria); Montolio, D., "Convergence and Inter-Distributional Dynamics among the Spanish Provinces. A Non-parametric Density Estimation Approach"

2001/8 - García Quevedo, J., "University research and the location of patents in Spain" Publicat a: Papeles de Economía Española, 93 pàgs. 98-108, sota el títol "Investigación universitaria y localización de las patentes en España" 


\section{SÈRIE DE DOCUMENTS DE TREBALL DE L'IEB}

2001/9 - Esteller, A.; Solé A., "Tax Setting in a Federal System: The Case of Personal Income Taxation in Canada"

Publicat a: International Tax and Public Finance, 9, pàgs. 235-57, 2002, sota el títol "An empirical analysis of vertical tax externalities: The case of personal income taxation in Canada"

2001/10 - Durán J.M.; Gispert, C. de, "Fiscalidad medioambiental sobre la energía: propuestas para España "

Publicat a: Energía, fiscalidad y medio ambiente en España, a A. Gago i X. Labandeira (Dir.), 7, pàgs. 171-192, 2002, sota el títol "La imposición energético-ambiental en España"

2001/11 - Álvarez, M., "España y la senda de desarrollo de la inversión directa: una aproximación"

\section{2}

2002/1 - Bosch, N.; Espasa, M.; Sorribas, P., "La capacidad redistributiva y estabilizadora del presupuesto del Gobierno Central Español"

Publicat a: Hacienda Pública Española/Revista de Economía Pública, 160 (1), pàgs. 47-76, 2002.

2002/2 - García Quevedo, J., "The location of innovation. Universities and technological infrastructure in Spain"

2002/3 - Viladecans Marsal, E., "The growth of cities: Does agglomeration matter?"

2002/4 - Pons Novell, J.; Tirado Fabregat, D.A. (UB), "Discontinuidades en el crecimiento económico en el periodo 1870-1994: España en perspectiva comparada"

2002/5 - Bosch, N.; Espasa, M.; Sorribas, P., "The redistributive, stabiliser and insurance effects at territorial level of "federal" government budgets"

2002/6 - Callejón, M. (UB); García Quevedo, J., "Las ayudas públicas a la I+D empresarial. Un análisis sectorial"

2003

2003/1 - Solé Ollé, A.; Viladecans Marsal, E., "Fiscal and growth spillovers in large urban areas"

2003/2 - Gual, J. (IESE); Trillas, F., "Telecommunications Policies: Determinants and Impact"

2003/3 - Leonida, L. (U. Della Calabria); Montolio, D., "Public Capital, Growth and Convergence in Spain. A Counterfactual Density Estimation Approach"

2003/4 - Álvarez, M., "FDI Determinant Factors: The Case of Catalan Multinational Manufacturing Firms"

2003/5 - Álvarez, M., "Wholly-Owned Subsidiaries Versus Joint Venture: The Determinant Factors in the Catalan Multinational Manufacturing Case"

2003/6 - Pelegrín, A., "Regional Distribution of Foreign Manufacturing Investment in Spain. Do agglomeration economies matter?"

\section{4}

2004/1 - Sánchez Hugalde, A., "Movilidad intergeneracional de ingresos y educativa en España (198090)" 


\section{SÈRIE DE DOCUMENTS DE TREBALL DE L'IEB}

2004/2 - Esteller, A., "Tax Evasion in Interrelated Taxes"

2004/3 - Castells, A.; Esteller, A.; Vilalta, M., "Full Characterisation of the Political Economy of Fiscal Adjustment: Evidence from Spanish Municipalities"

2004/4 - Lambert, P.J. (U. of York), "Income Taxation and Equity" 